\title{
Toxoplasmosis, a zoonotic infection; A critical and updated analysis: A Review Article
}

\author{
W. Nori ${ }^{\circledR}$ and A.I. Ali ${ }^{\circ}$ \\ Department of Obstetrics and Gynecology, College of Medicine, Mustansiriyah University, Baghdad, Iraq
}

\begin{tabular}{l} 
Article information \\
\hline Article history: \\
Received September 22, 2021 \\
Accepted November 24, 2021 \\
Available online December 15, 2021 \\
\hline Keywords: \\
Toxoplasmosis \\
Behavioral animal change \\
Schizophrenia \\
Lipid profile \\
Pregnancy \\
\hline Correspondence: \\
W. Nori \\
dr.wassan76@uomustansiriyah.edu.iq
\end{tabular}

\begin{abstract}
Toxoplasmosis is a parasitic illness caused by Toxoplasma gondii, an obligate intracellular protozoan. It may infect humans and pets, as well as other warm-blooded mammals. Toxoplasmosis can be silent in the general public but it can be deadly in immunocompromised patients. This neurotropic protozoan has been linked to an increased risk of behavioral changes in infected animals and mental illnesses in human beings. The detection of a biological pathogen linked to schizophrenia is critical to comprehend the pathogen's biological influence on affected cases. Moreover, in schizophrenia cases, toxoplasmosis infection and lipid profile disturbance are frequent. The exact underlying pathology is yet unknown. Pregnant women are a particular risk group; they are liable to a higher risk of infection, leading to miscarriage, stillbirth, or permanent impairments in the unborn child. This review aimed to explore the up-to-date knowledge on this zoonotic parasite and critically analyze current information, inconsistencies, and implications on public health. We discuss the pathological pathways by which it produces its devastating effect on the central nervous system in both animals and human models, in addition to its enigmatic impact on lipid profile.
\end{abstract}

DOI: 10.33899/ijvs.2021.131607.1980, (CAuthors, 2021, College of Veterinary Medicine, University of Mosul.

This is an open access article under the CC BY 4.0 license (http://creativecommons.org/licenses/by/4.0/).

\section{Introduction}

Toxoplasmosis, a disease caused by an intracellular parasite, Tosoplasma gondii is manipulating humans and animals with extensive distribution worldwide prevalent in a warm and moist environment (1,2). Tosoplasma gondii prevails in three forms: oocysts, tachyzoites, and bradyzoites. The life cycle is complex and includes two stages; the asexual cycle exists in any warm-blooded animal, like daogs, birds, pigs, in addition to humans (3). The sexual part started when the definitive host) final host; the cat) ingested the tissue cyst. The cyst stayed in the epithelial cells lining the small intestine (4). Then, the oocytes are excreted by the faeces of the cat and end the sexual part of the cycle. These oocytes can survive for more than one year (5). As for the prospective host, the human becomes infected following ingestion of undercooked meat contained the bradyzoites, which transforms into the sporozoites inside the body by the effect of $\mathrm{CO}_{2}$, enzymes and bile salts to settle in macrophages of the small intestine. Later it will leave intestine toward the endothelial cells of blood vessels and multiplication asexually there to produce the first generation of schizonts and merozoites. The later invade the endothelial cells of capillaries to produce the second generation of schizonts and merozoites at this time due to body immunity increase the parasite encysted as a bradyzoites among the muscles' fibers. Finally, sporozoites transformed into motile tachyzoites spread in the different parts of the body. Tachyzoites have rapid multiplication leading to the spreading of infection alongside tissue destruction $(6,7)$. Tosoplasma gondii life cycle is highlighted in Figure 1.

Moreover, it can cause fatal infection in pregnant women; it settles in the muscle tissue and the central nervous system and is transformed into bradyzoites or the tissue cyst (8). The diagnosis of toxoplasmosis can be direct by observing the $T$. gondii in the stained tissue, cerebrospinal 
fluid, blood or tissue biopsy. Today owing to the difficulties of performing these specimens, they are seldom used (9). Serological testing is the typical and reliable method to diagnose toxoplasmosis since the most ordinary form of infection is latent (10). Tosoplasma gondii causes intense and persistent humoral immune reaction associated with measurable antibody titers, regardless of clinical features among infected persons (11). The first detectable antibody one week after illness is the IgM, the earliest and most sensitive diagnostic marker in acute infection; however, it can be present for months or even one year (12). On the other hand, IgG could be detected one to two weeks after infection and reach a peak during the first one to two months, then decline later; thus, it is the standard test for chronic infection and continues as a residual titer long life. Other modalities of antibodies detection include the standard Sabin-Feldman Dye Test, Agglutination, Immunochromatographic, and Western Blotting tests (13).

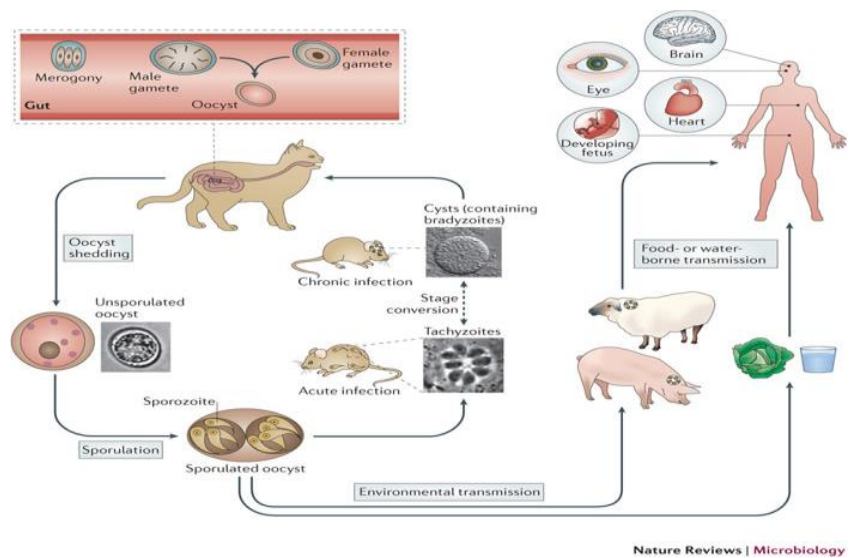

Figure1. Tosoplasma gondii life cycle (2).

\section{Toxoplasmosis infection and mental illness}

"Is insanity related to a microbial infection?" was a published editorial report in 1896 that started the debates on the infectious role in insanity pathogenesis (14). Emerging studies associated toxoplasmosis Tosoplasma gondii exposure with a wide range of mental illnesses, including autism, bipolar disorder, generalized anxiety disorder, pregnancy-related depression, and schizophrenia (15-17). Schizophrenia is a chronic disabling mental illness that affects how patients think, behave, display emotions, interpret reality, and interact with others (18).

$\mathrm{Xu} \mathrm{F}$ et al. (19), conducted a retrospective cross-sectional study of confirmed schizophrenic cases and healthy controls. Their study highlighted that anti-toxoplasmosis serum IgG was significantly higher in cases than healthy controls $(18 \%$ vs $7.4 \%$, P-value 0.0001, OR 2.77). Earlier research confirmed the same results among patients presented with the first attack of schizophrenia (20); moreover, their findings showed that the intensity of txoplasmosis infection was linked to several clinical signs of schizophrenia, such as aggression, poor attention, and stereotyped behavior, the neurocognitive consequences behind $T$. gondii infection in the brain is a subject of several theoretical theories.

Toxoplasmosis impact on the onset of mental disease is accredited to prasite-induced biochemical mechanisms. Chronic T. gondii infection alters brain neurobiology, namely -aminobutyric acid synaptic and signal transduction. However, other researchers postulated the immunological role of $T$. gondii infection. Higher amounts of proinflammatory cytokines, particularly IL-6, was significantly elevated among schizophrenic cases, raised inflammatory cytokines are the biological hallmark of schizophrenia, support this hypothesis (21-23).

During pregnancy, $T$. gondii parasite targets the growing fetal brain and causes congenital disabilities. Brown et al. (24) conducted a retrospective study that utilized maternal $\mathrm{IgG}$ serum levels to see if toxoplasmosis exposure during pregnancy is linked to a higher incidence of schizophrenia and associated disorders in adult children. A positive correlation was confirmed for those patients with a high category of $\operatorname{IgG}$ antibody titer, as for cases with moderate or minimal increase of the IgG titer, no meaningful correlation was scored, thus, it may be conceivable that the findings were due to a change in the mother immunological state $(24,25)$. Interestingly, Brown et al. (25) study included normal newborn babies upon delivery; no signs of congenital toxoplasmosis were demonstrated, which implies that toxoplasmosis infection produces comparable effects to those caused by rubella, influenza, and cytomegalovirus, and other infections linked to schizophrenia (26).

\section{Toxoplasmosis infection and behavioral changes in animal}

The effects of latent $T$. gondii infection on the central nervous system have been reviewed, a growing body of evidence supports neurologic and behavioral changes in animal models infected with latent toxoplasmosis, the infected rodents showed reduced learning, poor performance, and poor memory task achievements surprisingly, no cysts were identified in the hippocampi of afflicted animals, but they were located throughout the brain, suggesting that alterations in neurophysiology were to blame for the animal behavioral abnormalities (27).

Joanne et al. (28) have reported similar behavioral changes in mice and cats; the author interprets these changes as part of the invading neurotrophic parasite's manipulative function in completing its life cycle. Rodents' altered behavior makes them more vulnerable to predation by cats, the parasite's ultimate host. Later research has revealed that starting therapy can reverse $T$. gondii behavioral alterations. This discovery provides new avenues for the management of human schizophrenia. 
Iraqi Journal of Veterinary Sciences, Vol. 35, Supplement III, 2021 (95-99)

Proceedings of the 13th (2nd International) Scientific Conference, College of Veterinary Medicine, University of Baghdad

\section{Lipid profile}

In confirmed cases, both txoplasmosis infection and a lipid profile disturbance are prevalent; however, the underlying pathophysiological processes are unidentified; therefore, exploring the impact of chronic infection is crucial to get insight into the development of target therapeutic medicines (29). In their study on schizophrenic patients, Xu et al. (19) discussed that high-density lipoprotein and serum triglycerides are significantly elevated in seropositive cases $(\mathrm{P}=0.000)$, cholesterol, on the other hand, indicated the opposite tendency, the strong connection between confirmed clinical cases emphasized these findings even more $(\mathrm{OR}=0.62,95 \% \mathrm{CI}=0.51-0.748, \mathrm{P}=0.000)$.

$\mathrm{Xu}$ et al. (19) accredited these changes to the inability of T. gondii to produce cholesterol on its own; thus, it needs the host endocytosed low-density lipoprotein for cholesterol production; a key component of the parasitophorous vacuoles, because of increased absorption, $T$. gondii infection decreases blood cholesterol concentration in both infected humans and animals (19,30,31). Furthermore, gender differences in $T$. gondii infection were further highlighted in Sagud et al. (21) work that revealed higher blood concentrations of total cholesterol levels and lowdensity lipoprotein in $T$. gondii infected males. However, no meaningful changes were reported in schizophrenic female patients regarding lipid indicators.

Interestingly, Stürchler study investigated total cholesterol concentrations of serums' cord blood between seropositive and seronegative pregnant women; (280 vs. 279) respectively for cases and healthy controls. The difference was statistically insignificant (32). It is established that pregnancy is a state of immunological tolerance to the growing in utero fetus, which may modify the maternal response to infection; this may explain the lower total cholesterol in newborns (33). What backs up this explanation is the Marchioro results which showed that pregnant women with acute or chronic toxoplasmosis show less concentration of peripheral TNF- $\alpha$. The latter is a proinflammatory cytokine, which is ideally increased in adult $T$. gondii infection (34).

\section{Toxoplasmosis trend in pregnancy}

The infection can have a devastating effect on the growing fetus, resulting in abortion, stillbirth, brain calcification, ventriculomegaly, premature labor, and death. The infection can be transmitted to the fetus by transplacental passage during a primary infection in the mother, or it can be existing before conception in rare cases (35-37).

The probability of transmission is $30 \%$, and it is influenced by the gestational age and whether or not chemoprophylaxis is administered to pregnant women. The transmission rate is highest in the third trimester, with $70 \%$,
$46 \%$, and $13 \%$ at 36,26 , and 13 weeks of pregnancy, respectively. The sequence of infection, on the other hand, is the least in the third trimester (38).

According to some studies, if therapy is begun as soon as possible, the chance of transmission is reduced by up to $75 \%$. To capture this window of opportunity, comprehensive screening for maternal seroconversion is required. Confirming toxoplasmosis infection in the mother is a Delma. Although clinically speaking, the signs of illness are minor and mimic a flu-like sickness, $70 \%$ of people are clinically asymptomatic. As a result, establishing primary infection is dependent on maternal seroconversion from -ve to +ve $\operatorname{IgG}$ antibody, whereas $\operatorname{IgM}$ is a poor indicator of acute illness and can remain for years. The IgG avidity assay measures antibody binding strength to $T$ gondii; low avidity indicates acute infection, whereas high avidity indicates chronic infection (39).

The avidity and stability of a high IgG titer over onemonth rule out recent infection. Because of the catastrophic consequence of fetal toxoplasmosis, parents must be counselled about the significance of positive and negative testing since prevention is essential (40). It's vital to confirm the primary maternal infection to assess fetal transmission risk, give appropriate counselling, and begin antibiotics. Countries with high prevalence, like France, have implemented prenatal screening programs that have reduced the incidence by more than half (41). Olaru et al. (42). assessed the importance of starting therapy during pregnancy by comparing the newborn outcomes of infected women treated to those who were not. His findings revealed that treated mothers' babies had significantly lowered rates of ocular complications (38\% vs $62 \%$ ) and hydrocephalus $(67 \%$ vs $92 \%)$. Thus, even in countries where routine screening and treatment are not consistently followed, the author recommends anti-parasitic therapy for verified cases. As the use of the medication throughout pregnancy resulted in improved clinical results. In summary, many zoonotic diseases exist (43-47); Toxoplasmosis still has many layers still to be unraveled.

\section{Conclusion}

In conclusion, this review confirms a link between persistent $T$. gondii infection and schizophrenia. As a result, additional pathogens' co-infection should be considered. We also speculated on the possibility of a strong link between $T$. gondii infection and serum lipid modification in schizophrenia patients. a critical problem to be addressed in the treatment intervention for schizophrenia patients' lipid levels. Aiming to reduce vertical transmission and the incidence of severe neonatal toxoplasmosis, we strongly recommend adopting $T$. gondii screening programs in expectant mothers and treatment for women who contract toxoplasmosis during pregnancy. 
Iraqi Journal of Veterinary Sciences, Vol. 35, Supplement III, 2021 (95-99)

Proceedings of the 13th (2nd International) Scientific Conference, College of Veterinary Medicine, University of Baghdad

\section{Acknowledgments}

To our University, Al Mustansiriyah, for continuous support.

\section{Conflict of interest}

The authors declare that have no conflict of interests regarding the publication of this manuscript.

\section{References}

1. Stelzer S, Basso W, Silván JB, Ortega-Mora LM, Maksimov P, Gethmann J, Conraths FJ, Schares G. Toxoplasma gondii infection and toxoplasmosis in farm animals: Risk factors and economic impact. Food Waterborne Parasitol. 2019;15:e0037. DOI: 10.1016/j.fawpar.2019.e00037

2. Hunter C, Sibley L. Modulation of innate immunity by Toxoplasma gondii virulence effectors. Nat Rev Microbiol. 2012;10: 766-778. DOI: 10.1038/nrmicro2858

3. Peyron F, L'ollivier C, Mandelbrot L, Wallon M, Piarroux R, Kieffer F, Hadjadj E, Paris L, Garcia-Meric P. Maternal and congenital toxoplasmosis: diagnosis and treatment recommendations of a French multidisciplinary working group. Pathogens. 2019;8(1):24. DOI: 10.3390/pathogens 8010024

4. Omidian M, Ganjkarimi AH, Asgari Q, Hatam G. Molecular and serological study on congenital toxoplasmosis in newborn of Shiraz, Southern Iran. Environ Sci Pollut Res. 2021;28(13):16122-8.DOI: 10.1007/s11356-020-11707-X

5. Dubey JP. The history and life cycle of Toxoplasma gondii. New York: Academic Press; 2020. 1-19 p. DOI: 10.1186/s13071-020-04445-Z

6. Gómez-Chávez F, Canedo-Solares I, Ortiz-Alegria LB, Flores-Garcia Y, Luna-Pasten H, Figueroa-Damian R, Mora-González JC, Correa D. Maternal immune response during pregnancy and vertical transmission in human toxoplasmosis. Front Immunol. 2019;10:285. DOI: 10.3389/fimmu.2019.00285

7. Binquet C, Lejeune C, Seror V, Peyron F, Bertaux AC, Scemama O, Quantin C, Bejean S, Stillwaggon E, Wallon M. The cost-effectiveness of neonatal versus prenatal screening for congenital toxoplasmosis. PloS one. 2019;14(9):e0221709. DOI: 10.1371/journal.pone.0221709

8. Feleke DG, Gebreweld A, Zewde G. Toxoplasmosis in pregnant women and HIV/AIDS patients in Ethiopia: A systematic review and meta-analysis. J Parasitol Res. 2019:1. DOI: 10.1155/2019/4670397

9. Dupont D, Fricker-Hidalgo H, Brenier-Pinchart MP, Garnaud C, Wallon M, Pelloux H. Serology for Toxoplasma in immunocompromised patients: Still useful?. Trends Parasitol. 2020 9.DOI: $10.1016 /$ j.pt.2020.09.006

10. Garnaud C, Fricker-Hidalgo H, Evengard B, Alvarez-Martinez MJ, Petersen E, Kortbeek LM, Robert-Gangneux F, Villena I, Costache C, Paul M, Meroni V. Toxoplasma gondii-specific IgG avidity testing in pregnant women. Clin Microbiol Infect. 2020;26(9):1155-60. DOI: 10.1016/j.cmi.2020.04.014

11. Rostami A, Riahi SM, Gamble HR, Fakhri Y, Shiadeh MN, Danesh M, Behniafar H, Paktinat S, Foroutan M, Mokdad AH, Hotez PJ. Global prevalence of latent toxoplasmosis in pregnant women: A systematic review and meta-analysis. Clin Microbiol Infect. 2020;26(6):673-83. DOI: $10.1016 / \mathrm{j} . \mathrm{cmi} .2020 .01 .008$

12. Teweldemedhin M, Gebremichael A, Geberkirstos G, Hadush H, Gebrewahid T, Asgedom SW, Gidey B, Asres N, Gebreyesus H. Seroprevalence and risk factors of Toxoplasma gondii among pregnant women in Adwa district, northern Ethiopia. BMC Infect Dis. 2019;19(1):1-9. DOI: 10.1186/s12879-019-3936-0

13. Rostami A, Karanis P, Fallahi S. Advances in serological, imaging techniques and molecular diagnosis of Toxoplasma gondii infection. infection. 2018;46(3):303-15. DOI: 10.1007/s15010-017-1111-3
14. Torrey EF, Bartko JJ, Lun ZR, Yolken RH. Antibodies to Toxoplasma gondii in patients with schizophrenia: A meta-analysis. Schizophr Bull. 2007;33:729-736, DOI: $10.1093 / \mathrm{schbul} / \mathrm{sbl} 050$

15. Frye MA, Coombes BJ, McElroy SL, Jones-Brando L; Bond DJ, Veldic M, Romo-Nava F, Bobo WV, Singh B, Colby C. Association of cytomegalovirus andToxoplasma gondii antibody titers with bipolar disorder. JAMA Psychiatry. 2019;76:1285-1293. DOI: 10.1001/jamapsychiatry.2019.2499

16. Pedersen MG, Mortensen PB, Norgaard-Pedersen B, Postolache TT. Toxoplasma gondii infection and self-directed violence in mothers. Arch Gen Psychiatry. 2012;69:1123-1130,DOI: 10.1001/archgenpsychiatry.2012.668

17. Akaltun I, Kara S S, Kara T. The relationship between Toxoplasma gondii $\mathrm{IgG}$ antibodies and generalized anxiety disorder and obsessivecompulsive disorder in children andadolescents: A new approach. Nord J Psychiatry. 2018;72:57-62. DOI: 10.1080/08039488.2017.1385850

18. Ashwini R, Prasad BV, Kosgi S. Psychosocial intervention strategies for patients with schizophrenia: In chronic mental illness and the changing scope of intervention strategies. Diag Treat. 2017:58-75. DOI: $10.4018 / 978-1-5225-0519-8$.ch004

19. Xu F, Ma X, Zhu Y, Sutterland A, Cheng R, Miao S, Chen J, Qiu L, Zhou Y. Effects of Toxoplasma gondii infection and schizophrenia comorbidity on serum lipid profile: A population retrospective study from Eastern China. Microb Pathol. 2020;149:104587. DOI: 10.1016/j.micpath.2020.104587

20. Ebrahimzadeh A, Shahraki MK, Mohammadi A. Serological and molecular diagnosis of Toxoplasma gondii in patients with schizophrenia. J Parasit Dis. 2018;42(2):177-181. doi:10.1007/s12639018-0979-x

21. Sagud M, latkovic S, Svob Strac D, Sviben M, Zivkovic M, Vilibic M, Vuksan-Cusa B, Mihaljevic-Peles A, Pivac N. Latent Toxoplasma gondii infection is associated with decreased serum triglyceride to highdensity lipoprotein cholesterol ratio in male patients with schizophrenia. Compr Psychiatry. 2018, 82:115-120. DOI: 10.1016/j.comppsych.2018.02.002

22. Al Awam K, Haubleiter IS, Dudley E, Donev R, Brüne M, Juckel G, Thome J Multiplatform metabolome and proteome profiling identifies serum metabolite and protein signatures as prospective biomarkers for schizophrenia. J Neural Transm. 2015;122(s1):111-122. DOI: 10.1007/s00702-014-1224-0

23. Fernandez-Egea E, Miller B, Garcia-Rizo C,Bernardo M, Kirkpatrick B. Metabolic effects of olanzapine in patients with newly diagnosed psychosis. J Clin Psychopharmacol .2011;31:154-159. DOI: 10.1097/JCP.0b013e31820fcea3

24. Brown AS, Derkits EJ. Prenatal infection and schizophrenia: a review of epidemiologic and translational studies. Am J Psychother. 2010;167(3):261-80. DOI: 10.1176/appi.ajp.2009.09030361

25. Brown AS, Schaefer CA, Quesenberry Jr CP, Liu L, Babulas VP, Susser ES. Maternal exposure to toxoplasmosis and risk of schizophrenia in adult offspring. Am J Psychother. 2005;162(4):76773. DOI: $\underline{10.1176 / \text { appi.ajp.162.4.767 }}$

26. Blomstrom A, Gardner RM, Dalman C, Yolken RH, Karlsson H. Influence of maternal infections on neonatal acute phase proteins and their interaction in the development of non-affective psychosis. Transl Psychiatry. 2015;5(2):e502. DOI: 10.1038/tp.2014.142

27. Daniels BP, Sestito SR, Rouse ST. An expanded task battery in the Morris water maze reveals effects of Toxoplasma gondii infection on learning and memory in rats. Parasitol Inte. 2015;64(1):5-12. DOI: 10.1016/j.parint.2014.09.002

28. Joanne PW. The effect of Toxoplasma gondii on animal behavior: Playing cat and mouse. Schizophr Bull. 2007;33 (3):752-756. DOI: 10.1093/schbul/sbl073

29. Flegr J. Schizophrenia and Toxoplasma gondii: An undervalued association?. Expert Rev Anti Infect Ther. 2015;13(7):817-20. DOI: 10.1586/14787210.2015.1051033

30. Helkin A, Stein JJ, Lin S, Siddiqui S, Maier KG, Gahtan V. Dyslipidemia part review of lipid metabolism and vascular cell physiology. Vasc Endovascular Surg. 2016;50:107-118. DOI: $10.1177 / 1538574416628654$ 
31. Xu F, Lu X, Cheng R, Zhu Y, Miao S, Huang Q, Xu Y, Qiu L, Zhou Y. The influence of exposure to Toxoplasma gondii on host lipid metabolism. BMC Infect Dis. 2020;20:415. DOI: 10.1186/s12879-02005138-9

32. Sturchler D, Berger R, Just M. Congenital toxoplasmosis in Switzerland. Seroprevalence, risk factors and recommendations for prevention. Schweiz Med Wochenschr. 1987;117(5):161-7. [available at]

33. Poole JA, Claman HN. Immunology of pregnancy. Clin Rev Allergy Immunol. 2004;26(3):161-70. DOI: 10.1385/CRIAI:26:3:161

34. Marchioro AA, Colli CM, de Souza CZ, da Silva SS, Tiyo BT, Evangelista FF, Higa L, Conchon-Costa I, Falavigna-Guilherme AL. Analysis of cytokines IFN- $\gamma$, TNF- $\alpha$, TGF- $\beta$ and nitric oxide in amniotic fluid and serum of pregnant women with toxoplasmosis in southern Brazil. Cytokine. 2018;106:35-9. DOI: 10.1016/j.cyto.2018.02.023

35. Nori W, Abdulghani M, Roomi AB, Akram W. To operate or to wait? Doppler indices as predictors for medical termination for first trimester missed abortion. Clin Exp Obstet Gynecol. 2021;48(1):168-74. DOI: 10.31083/j.ceog.2021.01.2215

36. Bigna JJ, Tochie JN, Tounouga DN, Bekolo AO, Ymele NS, Youda EL, Sime PS, Nansseu JR. Global, regional, and country seroprevalence of Toxoplasma gondii in pregnant women: a systematic review, modelling and meta-analysis. Scie Rep. 2020;10(1):1-0. DOI: 10.1038/s41598-020-69078-9

37. Nori W, Ali AI. Maternal alpha-1-antitrypsin as a noval marker for growth restriction in pre-eclampsia. J Obstet Gynaecol Res. 2021;47(12):4250-4255. DOI: 10.1111/jog. 15043

38. Bhutta ZA, Das JK, Bahl R, Lawn JE, Salam RA, Paul VK, Sankar MJ, Blencowe H, Rizvi A, Chou VB, Walker N. Can available interventions end preventable deaths in mothers, newborn babies, and stillbirths, and at what cost?. The Lancet. 2014;384(9940):347-70. DOI: 10.1016/S0140-6736(14)60792-3

39. Cortina-Borja M, Tan HK, Wallon M, Paul M, Prusa A, Buffolano W, Malm G, Salt A, Freeman K, Petersen E, Gilbert RE. Prenatal treatment for serious neurological sequelae of congenital toxoplasmosis: an observational prospective cohort study. PLoS Med. 2010:1-11. DOI: 10.1371/journal.pmed.1000351

40. Khan K, Khan W. Congenital toxoplasmosis: An overview of the neurological and ocular manifestations. Parasitol Int. 2018;67(6):71521. DOI: $10.1016 /$ j.parint.2018.07.004

41. Nogareda F, Le Strat Y, Villena I, De Valk H, Goulet V. Incidence and prevalence of Toxoplasma gondii infection in women in France, 19802020: model-based estimation. Epidemiol Infe. 2014;142(8):1661-70. DOI: $10.1017 /$ S0950268813002756

42. Olariu TR, Press C, Talucod J, Olson K, Montoya JG. Congenital toxoplasmosis in the United States: Clinical and serologic findings in infants born to mothers treated during pregnancy. Parasite. 2019;26. DOI: 10.1051/parasite/2019013

43. Aghwan SS, Al-Bakri HS, Albaqqal SM. Comparison the efficiency of different techniques for the diagnosis of Toxoplasma gondii infection in slaughtered ewes. Iraqi J Vet Sci. 2021;35(2):661-666. DOI: 10.33899/ijvs.2021.127058.1452
44. Al-Mallah KH, Aghwan SS, Alsarhan QT. Comparative study on the effect of cadmium and hydrocortisone treatment on the brain of rats experimentally infected with Toxoplasma gondii. Iraqi J Vet Sci. 2021;35(4):771-5. DOI: 10.33899/ijvs.2021.128436.1575

45. Shaapan R, Toaleb NI, Abdel-Rahman EH. Detection of Toxoplasma gondii-specific immunoglobulin (IgG) antibodies in meat juice of beef. Iraqi J Vet Sci. 2021;35(2):319-24. DOI: 10.33899/ijvs.2020.126829.1390

46. Al-Sanjary RA, Hussein TH. Using species-specific PCR technique to detect Toxoplasma gondii in broiler chickens. Iraqi J Vet Sci. 2012 28;26(2):53-6. DOI: 10.33899/ijvs.2012.67452

47. A'aiz NN. Determination of Toxoplasma gondii lineages of sheep in Wasit, Iraq. Iraqi J Vet Sci. 2016;30(2):23-6. DOI: 10.33899/ijvs.2016.121379

\section{داء المقوسات، عدوى حيوانية المنشأ؛ تحليل نقدي محدث: دراسة مراجعة عدو أوس وسن نوري و الاء إبراهيم علي}

قسم النسائية و التوليد، كلية الطب، الجامعة المستصصرية، بغداد، العراق

داء المُقَََسَّات هو مرض طفيلي تسببه المقوسة الكوندية، و هو طفيلي

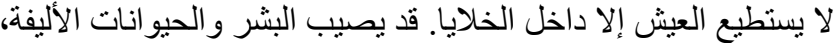

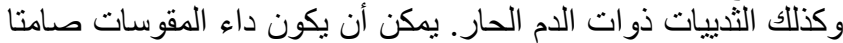

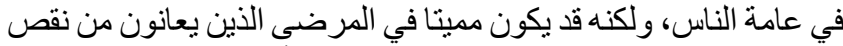

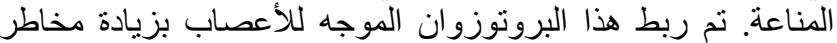

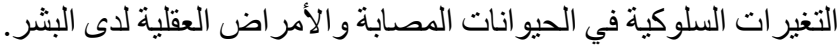

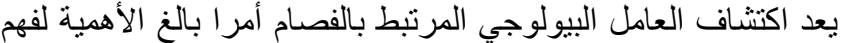

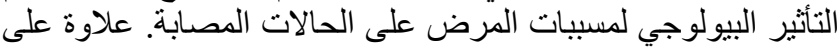

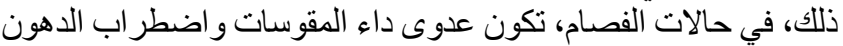

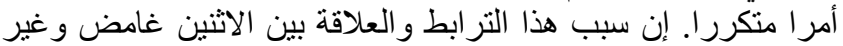

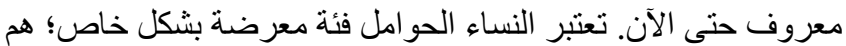
عرضة لخطر أكبر للإصابة بالعدوى، مما يؤدي إلى الإجهاض أو أو و لادة

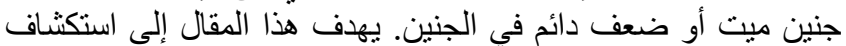

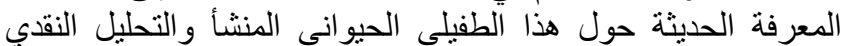

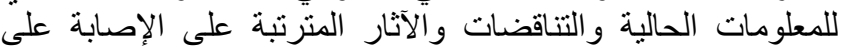

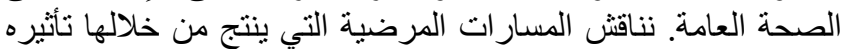

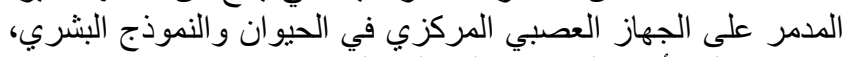
بالإضافة إلى تأثيره الغامض على على ملف الدهون. 